prevention of rust on wheat and other cereals and on weed killing, have already proved of great economic advantage to the whole country as well as to the particular industries. There is scarcely one of Canada's wide range of interests - agriculture, mineral industries, transport, fisheries, building, fruit growing, coal, leather, wool-to which the Laboratories are not offering direct service. Highly important work has already been carried out on rubber and extensive facilities have been provided for standardising and testing all classes of materials.

\section{Metropolitan-Vickers Research and Testing Departments}

A BookLwT which has just been issued, describing the Research and Testing Departments of the Metropolitan-Vickers Electrical Co., Ltd., Trafford Park, Manchester, shows what an important part industrial research plays in the advancement of science. The somewhat fragile and makeshift construction of the equipment of many science laboratories is often due to an excessive use of glass, rubber and similar materials. Modern engineering principles, materials and manufacturing methods have led to great improvements. The original research work carried out by the scientific staff of the Company has led to many important developments. In particular, the discovery of the Apiezon series of low-pressure oils and distillates has led to highly important advances in vacuum technique. Valves, $\mathrm{X}$-ray tubes, etc., can now be taken to pieces for repair and adjustment and then re-assembled for use. They can also be made of materials like metal and porcelain and so have not the disadvantages of permanently sealed glass apparatus. The physics and engineering staff have done excellent pioneering work in many branches of research. Their vacuum furnaces, their arrangement of apparatus to apply testing pressures of a million volts continuously and their testing methods for impulse pressures as high as one and a half million volts are scientific triumphs. In developing apparatus for measuring noise they have broken new ground. The principle on which the apparatus works is that of aural comparison of the complex noise under observation with a pure reference tone of fixed frequency but adjustable amplitude. By listening simultaneously to the two sounds and adjusting the loudness of the reference tone until it sounds as loud as the noise under observation, the loudness of the complex noise can be expressed, by an experienced observer, in terms of that of the simple reference tone.

\section{Railway Electrification Experience}

Col. Contez Leigh, electrical engineer to the London, Midland and Scottish Railway Co., read a paper to the Institution of Electrical Engineers on April 6, which attracted a large audience. He described the experience gained by working the electrical railway between Manchester and $\mathrm{Al}$ trincham, a distance of about nine miles, since it was opened in May 1931. It appears that notwithstanding the competition of a recently inaugurated express bus service, the increase in the passenger traffic was 35 per cent. This is attributed to the greatly accelerated service made possible by electrification and to the increased comfort of travelling. Another reason is the great success of the 1,500-volt mercury arc rectifiers, the first used in Great Britain for railway work, for converting the alternating current supply into direct current for the railway motors. It looks as if these devices would come into general use, seeing that the 1,500 volt D.C. system was standardised by the Pringle Committee in 1927. This will make it easy to merge into a general scheme of main line electrification later. In the discussion, H. W. H. Richards, electrical engineer of the London and North Eastern Railway, compared the straight electric drive adopted on this line with the Diesel electric drive which has been much advocated lately. He calculated that the straight electric drive takes forty per cent less power. Prof. W. Cramp referred to the wear of the overhead conductors which are in contact with the pantograph collectors. It has been found that the wear of the conductors when the wires are oiled is about six times less than when there is no oil. Sir Josiah Stamp said that the results obtained on this line have more than fulfilled expectations.

\section{The Palæontographical Society}

THE eighty-sixth annual meeting of the Palæontographical Society was held in the rooms of the Geological Society, Burlington House, on Friday, April 28, Dr. F. L. Kitchin, vice-president, in the chair. The annual report recorded the publication of vol. 84 of the monographs, containing instalments of the Corallian Lamellibranchs, Gault Ammonites, and Cambrian Trilobites. It is anticipated that vols. 85 and 86 will be issued during the present year, thus bringing the publications more nearly up to date. Dr. F. A. Bather, Mr. Robert S. Herries, and Sir A. Smith Woodward, were re-elected president, treasurer, and secretary respectively; and Mr. F. H. Edmunds, Dr. W. D. Lang, Prof. S. H. Reynolds, and Prof. W. W. Watts were elected new members of council.

\section{Science Forum}

However on financial grounds the apparently unending stream of new scientific organisations and publications may be deplored, one cannot honestly withhold sympathy when these are founded with the object of promoting international co-operation in the general advancement and practical development of science in all its phases. The first issue of the Science Forum, the quarterly journal of the International Faculty of Sciences, is therefore of interest as an indication of the manner in which it is proposed to achieve these objects. The articles include discussions on the relation of science and religion by Dr. Ernst Almquist, and on changes in moral ideas likely to result from the study of psychology in relation to ethics by Dr. R. Money-Kyrle. W. H. Wakinshaw's "Consuflatia" provides a useful elucidation (with an unconvincing solution) of the world's economic problems, and an interesting note on the gladiolus scab and its prevention comes from 